\title{
HYDRAULICS OF CLEAR OVERFALL WEIRS WITH BOTTOM-OPENINGS
}

\section{Gamal Abozeid", Hassan I. Mohamed" and Salah M. Shehata}

Prof., Civil Eng. Dept., Assiut Univ., 71516 Assiut, Egypt.

**Associate Prof., Civil Eng. Dept., Assiut Univ., Assiut, Egypt.

**** Eng., Ministry of Water Resources and Irrigation, Egypt.

e-mail: hassanmohamed_2000@yahoo.com

(Received October 1, 2009 Accepted October 22, 2009)

Many Fayoum Standard Weirs have been perforated by one, two or three pipes, to convey much water in downstream direction. Measurements of discharge with these structures are complicated due existence of the opening. In this research, an experimental study was carried out to investigate the flow over clear over fall weir with bottom opening. Nine weir models with different heights were tested in horizontal laboratory flume of $17 \mathrm{~m}$ length, $0.3 \mathrm{~m}$ width, and $0.5 \mathrm{~m}$ depth. Weir height is changed three times. For each one, the diameter of opening is changed three times. The downstream depth was changed to cover all the expected flow regimes of the pipe and the weir. These flow regimes are; free pipefree weir, submerged pipe-free weir and submerged pipe-submerged weir. The results of flow over weir with opening were compared with those of weir without opening having the same dimensions. It was found that there is a large deviation between them. Multiple regression equations based on energy principal and dimensional analysis theory were developed for computing discharge over clear over fall weir with bottom opening. Also, values of discharge coefficients were estimated for combined flow over the weir and through the pipe. Then the total discharge can be computed by multiplying the discharge coefficient by the summation of theoretical weir discharge plus theoretical orifice discharge. Equations for computing the discharge of combination are awarded.

KEYWORDS: Fayoumi weir, bottom opening, discharge coefficient.

\section{INTRODUCTION}

Weirs may be used for proper distribution of water to canals for irrigation, reducing the hydraulic slope in the canals, reducing the acting head on regulators etc.. With the increase of cultivated area served by canals, water demands becoming higher. As a result the capacity of the existing weirs built on those canals and the embankment of the canals themselves upstream of the weirs becoming insufficient to pass this increase of high water demands. So, the solution is to replace the old structures by new ones or to modify the existing ones. The first solution is costly prohibitive while the second requires a modification of the hydraulic characteristics of the weirs. The modifications may be the widened or lowering weir crest or operating the existing pipes used at the bottom for emptying the canals to pass extra flow rates to downstream.

Clear over fall weirs are common engineering structures in irrigation system in 
Egypt, especially in Fayoum district. The name "Fayoum standard weir" became worldwide known [1]. Weirs, gates and pipes are usually used individually. A combination of two of them may be used too. Works concerning the flow over weirs have been mentioned by Boss et al. [5], Göğüş et al. [7], Hager and Schwalt [8], Mohamed [9], Sargison, and Percy [17], and many others. A combination of a weir and a gate has been studied recently by many engineers and investigators. Among of them are Alhamid [2], Alhamid et al. [3], Ansar [4], Ferro [6], Negm et al. [13-15]. Depending on the pipe conditions and the water elevation on either side of the weir, flow is classified into three different flow categories [1 and 16]. More specifically those categories are; Free orifice where the pipe is free pipe, submerged orifice with free weir and submerged pipe and submerged weir.

Wolters et al. [18] made serious attempts to calculate the discharge for system consisted of a specific weir and a pipe. They made a distinction between flow over the weir, which can be calculated rather accurate, and the flow through the pipes, which is far less reliable. They suggested rating curves for all weirs they studied.

Abdel halim et al. [1] calibrated experimentally the flow over existing Fayoum weirs with orifices. They suggested that, calibration must be based only on water head over the crest of the weir $H$, which is the only measurable parameter in the field. They introduce equation for computing the discharge, but they show that this equation is based on the dimensions of the model used in their work. Therefore, it can not be used as a general case in the field. Negm [10-12] conducted extensive experimental study to the characterististics of combined flow over sharp-edged and below a gate with different shapes and different flow conditions and introduced a general dimensionless relationships for predicting the discharge of the combined flow through these devices. It is noticed that most of previous works for discharge measurement structures were carried out on weirs without pipe or on sharp crested weirs with non-circular openings. However, in irrigation system, like the Fayoum irrigation system, weirs are not sharp crested and are fed with circular opening. The main purpose of this research is to determine the relationship between the flow passing through the pipe and over the weir to know how much the pipe can affect the flow passing over the weir.

\section{LABORATORY EXPERIMENTS}

Laboratory experiments were carried out in open channel glass side tilting flume type. At the outlet of the flume, there was a tailgate to regulate the water levels. In all of experiments, discharge was regulated by a gate valve and was regulated by an orifice meter fitted to a pipeline which feeds water to the flume. Water surface profile and water levels were obtained by a point gauge.

Nine models have been built from sand-cement mortar with different heights and openings made of PVC pipes. Figure (1) shows definition sketch of the models used in the experiments. The experiments were conducted for various range of weir height $\mathrm{P}$, opening diameter, $\mathrm{D}$, discharge and downstream water depth to cover the three cases of flow over the weir i.e. free pipe- free weir (case one), submerged pipe- free weir (case two) and submerged pipe- submerged weir (case three). Ranges of experiment parameters are listed in Table (1). 
Table (1): Experimental conditions for the experiments.

\begin{tabular}{|l|c|c|c|c|c|}
\hline \multirow{2}{*}{ Parameter } & \multirow{2}{*}{ Symbol } & \multirow{2}{*}{ Value } & \multicolumn{2}{|c|}{ Range } & \multirow{2}{*}{ Units } \\
\cline { 4 - 5 } & & & From & To & \\
\hline Height of weir & $\mathrm{P}$ & $10,14.6,20$ & 10 & 20 & $\mathrm{~cm}$. \\
\hline Diameter of pipe & $\mathrm{D}$ & $4.5,5.4,7.0$ & 4.5 & 7.0 & $\mathrm{~cm}$. \\
\hline Upstream water depth & $\mathrm{y}_{1}$ & varied & 13.4 & 28.45 & $\mathrm{~cm}$. \\
\hline Downstream water depth & $\mathrm{y}_{2}$ & varied & 1.75 & 24.85 & $\mathrm{~cm}$. \\
\hline Head over the weir & $\mathrm{H}$ & varied & 3.95 & 8.55 & $\mathrm{~cm}$. \\
\hline Discharge & $\mathrm{Q}$ & varied & 5.91 & 17.37 & $\mathrm{Lit} / \mathrm{sec}$. \\
\hline Downstream Froude No. & $\mathrm{Fe}$ & varied & 0.06 & 0.25 & - \\
\hline
\end{tabular}

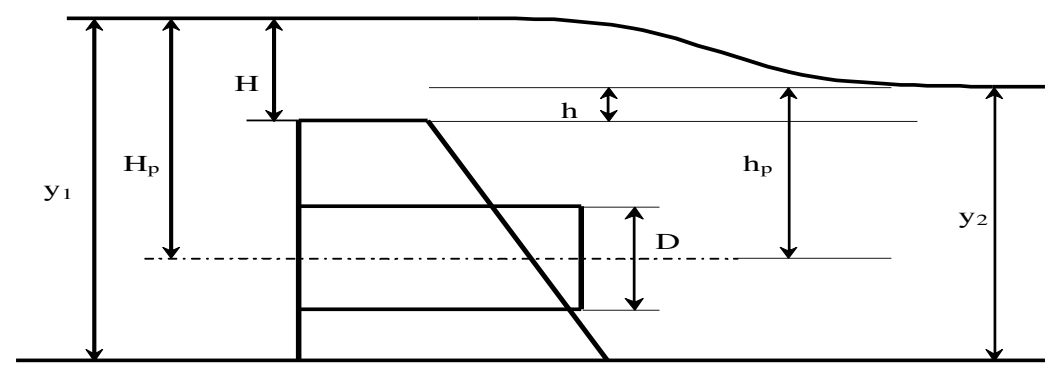

Fig. (1): Definition sketch of the used models.

\section{THEORETICAL APPROACHES}

\section{1- Discharge Equations Based on Energy Principals}

Flow over a rectangular weir without lateral contractions and a non- submerged hydraulic jump can be described by [1]:

$$
Q_{a c t w}=\frac{2}{3} C_{d w} B \sqrt{2 g} H^{1.5}
$$

In which $Q_{a c t w}$ is the actual discharge passes over the weir, $C_{d w}$ is the coefficient of discharge, $B$ is the width of the weir, $g$ is the gravitational acceleration and $\mathrm{H}$ is the water head over the weir. Also, Flow through the pipe is governed by the following equation for the orifice discharge [1]:

$$
Q_{a c t p}=\frac{\pi}{4} D^{2} C_{d p} \sqrt{2 g H_{P}}
$$

In which $Q_{a c t p}$ is the actual discharge through the pipe, $C_{d p}$ is the coefficient of discharge, $g$ is the gravitational acceleration and $\mathrm{Hp}$ is the difference of head of water over the pipe $=(H p-h p)$, see Fig. 1 .

Thus, any relation controls the flow passing with combined device $\left(Q_{\text {actc }}\right)$ consisted of weir and pipe must use these equations to illustrate the interaction that 
happened in between. The following equation may be used in providing relation between discharge over weir and discharge through pipe:

$$
Q_{a c t c}=Q_{a c t w}+Q_{a c t p}
$$

or

$$
C_{d} Q_{t h}=C_{d w} Q_{t h w}+C_{d p} Q_{t h p}
$$

Where $Q_{t h}, C_{d}$, are the theoretical discharge and the coefficient of discharge of combined device, respectively and $Q_{t h w}, Q_{t h p}$ are the theoretical discharges passing over the weir that passing through the pipe respectively. From Eq. (4), one can easily get the following form:

$$
C_{d}=C_{d w} \frac{Q_{t h w}}{Q_{t h}}+C_{d p} \frac{Q_{t h p}}{Q_{t h}}
$$

The values of $C_{d}, C_{d w}$ and $C_{d p}$ may be experimentally estimated.

\section{2- Dimensional Analysis}

A physically pertinent relation between the discharge and the other dependent parameters may be found by dimensional analysis. The non-dimensional relationship is also useful for checking the sensitivity of the different parameters which affect the phenomenon [9]. The functional relationship of the discharge $\mathrm{Q}$ may be expressed by:

$$
\Phi_{1}\left(B, P, H, y_{1}, y_{2}, D, \rho, \mu, g, Q\right)=0
$$

where, $\mathrm{B}$ is weir width, $\mathrm{P}$ is weir height, $\mathrm{H}$ is upstream water head over the weir, $\mathrm{y}_{1}$ is upstream water depth, $y_{2}$ is downstream water depth, $D$ is diameter of the pipe, $\rho$ is water density, $\mu$ is dynamic viscosity of the fluid and $g$ is gravitational acceleration. Using $\pi$-theorem and applying the properties of dimensional analysis, it yields;

$$
\frac{Q}{B D^{1.5} \sqrt{2 g}}=\phi_{2}\left(\frac{H+D}{P}, \frac{H}{D}, \frac{y_{1}-y_{2}}{D}, \frac{\rho Q}{D \mu}\right)
$$

In which $\frac{\rho Q}{D \mu}=$ Reynolds Number, in open channel flow, Reynolds Number effect may be neglected [9]. The width of the weir is constant, so, Eq. (7) may take the following form:

$$
\frac{q}{D^{1.5} \sqrt{2 g}}=\phi_{3}\left(\frac{H+D}{P}, \frac{H}{D}, \frac{y_{1}-y_{2}}{D}\right)
$$

Where: $\mathrm{q}$ is discharge per unit width of weir, the left hand term represents the dimensionless discharge value and will called $C_{D}$ in the following analysis for simplicity. Thus, Eq. (8) can be re-written as follow:

$$
C_{D}=\phi_{4}\left(\frac{H+D}{P}, \frac{H}{D}, \frac{y_{1}-y_{2}}{D}\right)
$$

In the following section the dimensionless groups in Eqn. (9) will be correlated to give explicit equations for computing the discharge over the combined weir-pipe device for all cases of flow. 


\section{RESULTS AND DISCUSSIONS}

\section{1- Water Surface Profiles:}

Figure (2) shows the variation of upstream water depth, $y_{1}$, with the downstream water depth, $y_{2}$, at weir height equal to $10 \mathrm{~cm}$, pipe diameter equal to $5.4 \mathrm{~cm}$ and discharge of 12.98 lit./sec. (as an example). The upstream water depth remains constant for free flow through the opening and begins to rise when the downstream water depth becomes higher than the opening or crest levels respectively. The rate on increase in upstream water depth is higher when both the opening and the weir are submerged, for this the flow can be divided to three cases as illustrated before.

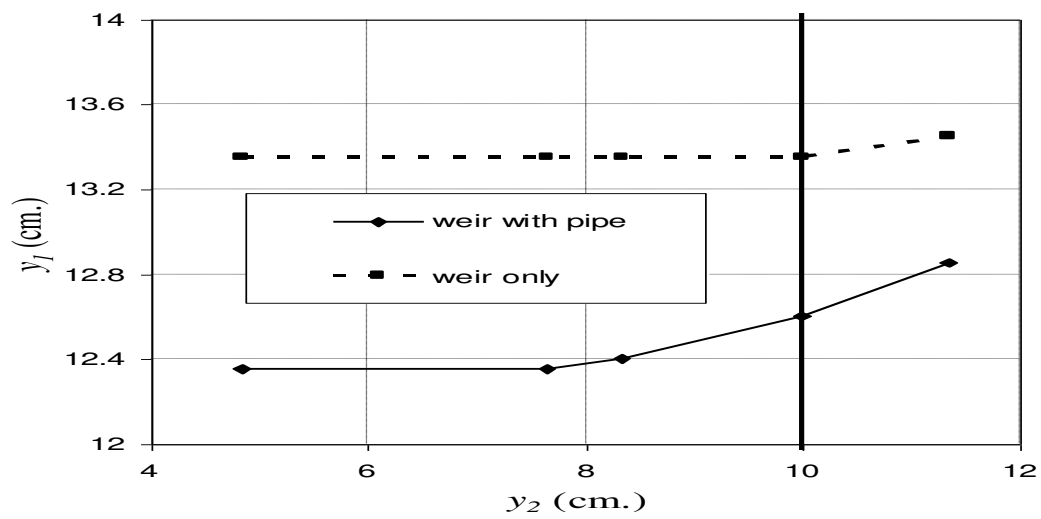

Fig. (2): Variation of $\mathrm{y}_{1}$ with $\mathrm{y}_{2}$ at weir height $P=10 \mathrm{~cm}$ and pipe diameter $D=5.4 \mathrm{~cm}$.

Water surface profiles for weir with opening and weir without opening are drawn as in Fig. (3) for the case of submerged pipe-free weir as an example. It can be seen that the hydraulic jump behind the weir with opening occurs nearer to the weir than that at weir without opening. This may affect the scour characteristics downstream the weir. Also, the upstream water depth is higher for weir without opening than that at weir with opening. So, the existence of bottom pipe to pass discharge increases the canal conveyance efficiency upstream of the weir.

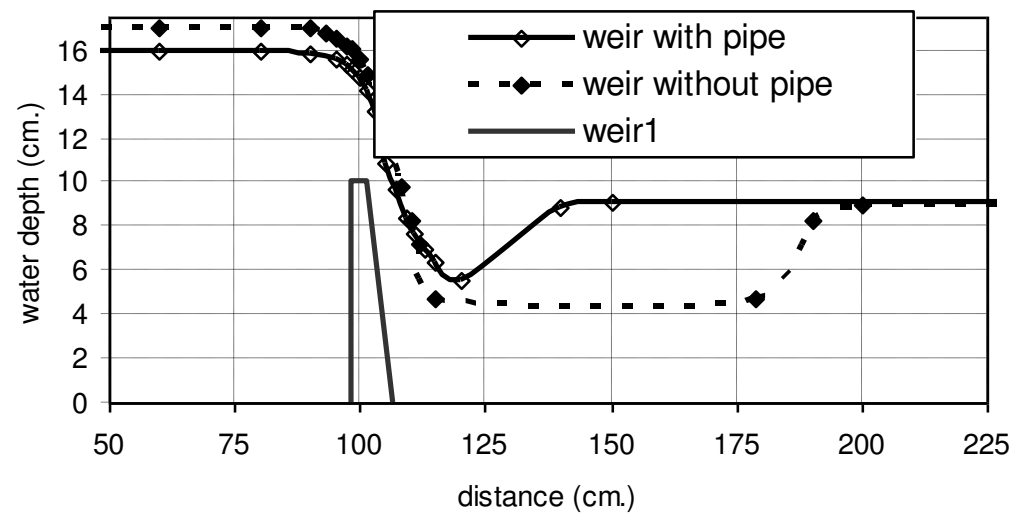

Fig. (3): Water surface profiles over weir at $P=10 \mathrm{~cm}, \mathrm{D}=5.4 \mathrm{~cm}$ and $\mathrm{Q}=12.98 \mathrm{lit} / \mathrm{sec}$.. 
In Fig. (4), it is shown the variation of upstream water depth with discharge at different opening diameters for the same weir height. The upstream water depth increases linearly with the increase of the discharge for same opening. At same discharge, the upstream water depth decreases by increasing of opening diameter.

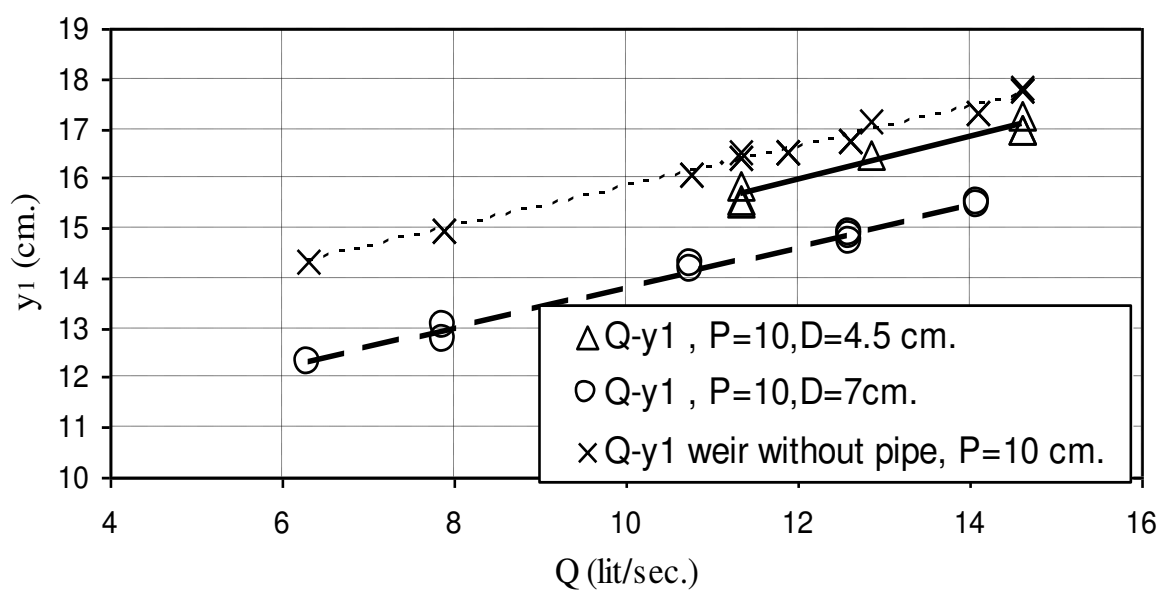

Fig. (4): Variation of upstream water depth with discharge for weir with pipe and without pipe at weir height $=10 \mathrm{~cm}$.

The effect of different dimensionless parameters derived earlier on the discharge as dimensionless value is explored. Figures (5 to7) show the variation of dimensionless discharge values $C_{D}$ with the dimensionless parameters $(H+D) / P, H / D$ and $(y 1-y 2) / D$ for different pipe diameters. It is shown that the dimensionless discharge values increase linearly with these parameters.

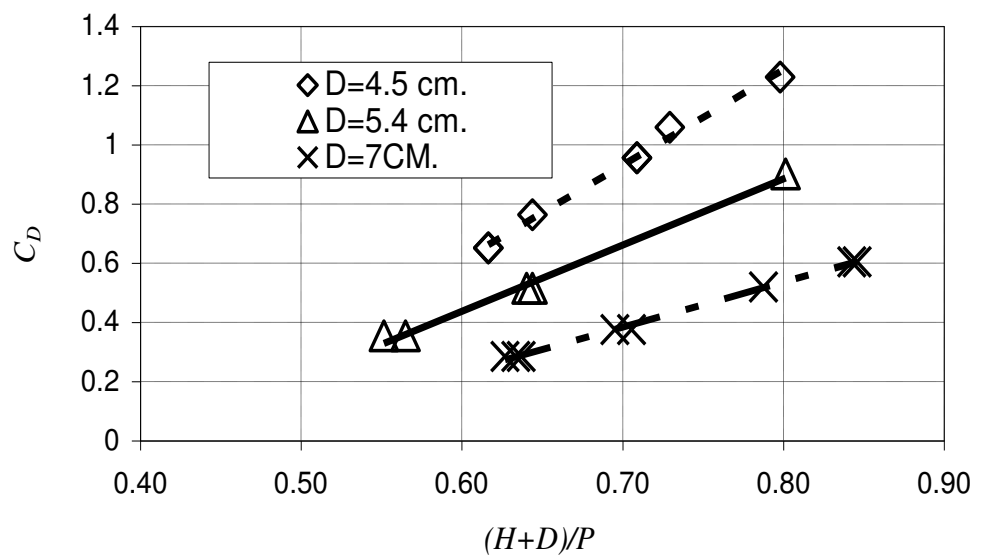

Fig. (5): Variation of dimensionless discharge value with dimensionless parameter $(H+D) / P$ at weir height $=14.6 \mathrm{~cm}$. 


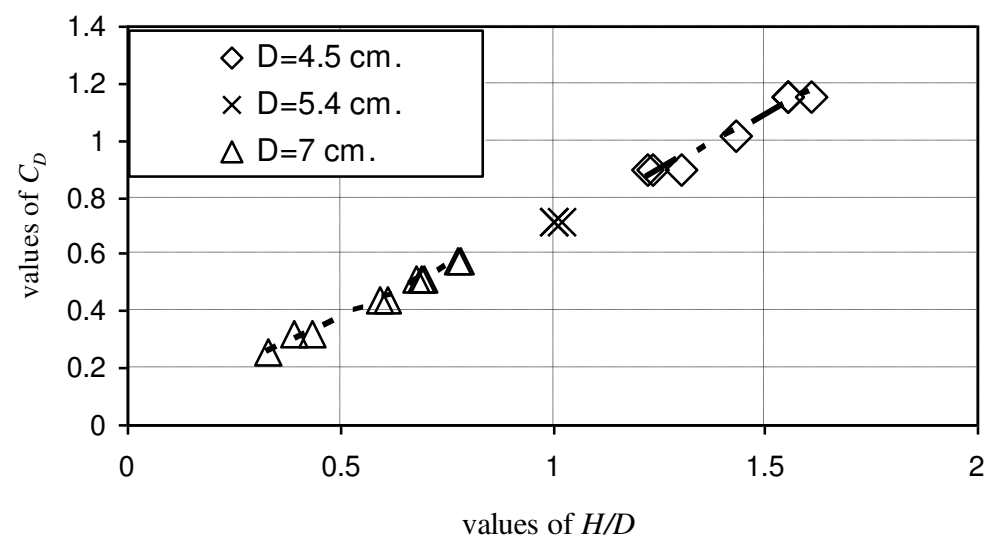

Fig. (6): Variation of dimensionless discharge value with dimensionless parameter $H / D$ at weir height $=10 \mathrm{~cm}$.

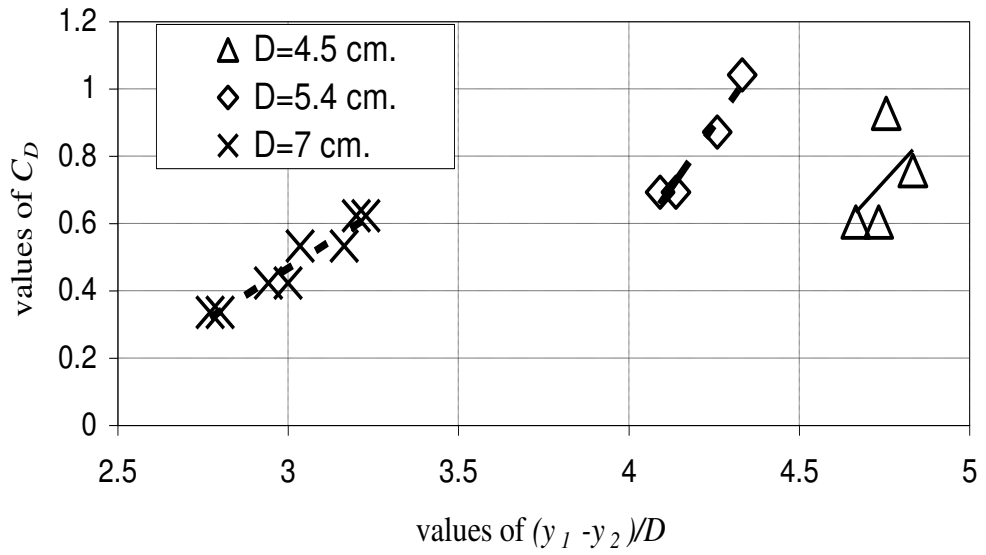

Fig. (7): Variation of dimensionless discharge value with dimensionless parameter $\left(y_{1-} y_{2}\right) / D$ at weir height $=20 \mathrm{~cm}$.

A multiple regression analysis is used for correlating the different dimensionless parameters shown in Eqn. (8) to develop an empirical equation for computing the discharge over clear over fall weir with bottom circular-opening at different flow conditions. The developed equation can be expressed as follows;

$$
\frac{q}{D^{1.5} \sqrt{2 g}}=A_{1}+A_{2} \frac{H+D}{P}+A_{3} \frac{H}{D}+A_{4} \frac{y_{1}-y_{2}}{D}
$$

where $A_{1}, A_{2}, A_{3}$ and $A_{4}$ are parameters depending on flow condition and their values are shown in Table (2). The coefficient of correlation $\mathrm{R}^{2}$ and the standard error in estimating these parameters are 0.97 and 0.04 , respectively.

Table (2): Values of coefficients in Eqn. (9).

\begin{tabular}{|l|c|c|c|c|}
\hline Flow condition & $A_{1}$ & $A_{2}$ & $A_{3}$ & $A_{4}$ \\
\hline Free pipe-free Weir & 0.01 & 0.025 & 0.68 & 0.012 \\
\hline Submerged pipe- free weir & -0.11 & 0.11 & 0.71 & 0.024 \\
\hline Submerged pipe- submerged weir & -0.17 & 0.11 & 0.58 & 0.21 \\
\hline
\end{tabular}


The values of computed discharge ( $\mathrm{Q}$ computed in lit/sec.) from regression analysis, (Eqn. 9) versus the measured ones (Q observed in lit/sec.) for the three studied cases of flow. There is a well agreement between computed discharges and measured ones.

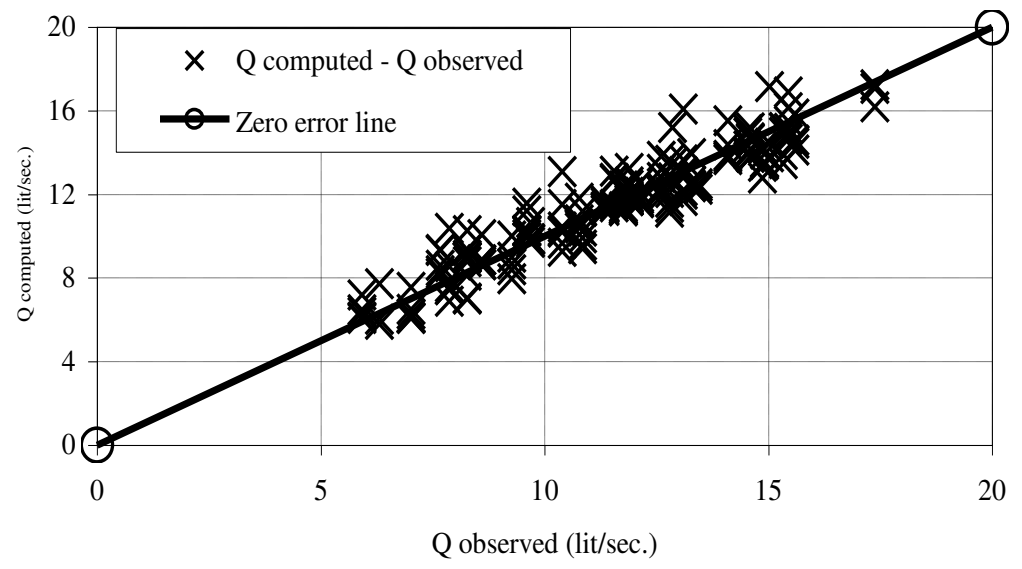

Fig. (8): Value of computed discharge using Eqn. (4) versus measured one.

Based on Eq.(5) and the measured data and using the regression analysis, one can estimate the average values of $C_{d w}$, and $C_{d p}$ and consequently the total discharge passing with the combined device of weir and bottom opening. It is found for the range of the experiments that the values of $C_{d w}$, and $C_{d p}$ depend on the flow condition as shown in Table (3).

Table (3): Values of coefficients in Eqn. (5).

\begin{tabular}{|l|c|c|c|c|}
\hline Flow condition & $C_{d w}$ & $C_{d p}$ & $R^{2}$ & SEE \\
\hline Free pipe-free Weir & 0.769 & 0.827 & 0.997 & 0.038 \\
\hline Submerged pipe- free weir & 0.746 & 1.052 & 0.996 & 0.052 \\
\hline Submerged pipe- submerged weir & 0.641 & 1.535 & 0.995 & 0.057 \\
\hline
\end{tabular}

\section{CONCLUSIONS}

The finding from this research may have practical applications especially when operating the existing bottom pipes to increase conveyance efficiency of the channel upstream the weirs and also to increase the discharge passing to downstream channel. The following main conclusions may be drawn:

1- The division of flow passing with combined device affectes the flow characteristics downstream, where for weir with bottom opening, the hydraulic jump behind it is formed at shorter distance than that with weir without opening.

2- Operating bottom pipes for passing flow with that passing over weir crest decreases the upstream water depth, consequently increases the conveyance efficiency of the upstream channel and increases the flow passing capacity of the weir. 
3- The downstream water depth affects the upstream water depth for weir with opening when the opening becomes submerged.

4- Based on dimensional analysis and energy concepts, equations are developed for computing the discharge through the combined device for all conditions of flow.

\section{REFERENCES}

1. Abdel Halim, N. A., Sherif, M. M., and El-Zaher, A. S.,"On the Fayoum Weirs with Orifices ", J. of Eng. and Applied Scie., Faculty of Eng., Cairo Univ., Egypt, Vol. 38, No. 5, pp. 893-904. 1991.

2. Alhamid, A. A., "Analysis and Formulation of Flow through Combined V-nochgate Device" J. of Hyd. Res., Vol. 37, No. 5, pp 697-705, 1999.

3. Alhamid, A. A., Negm, A. M. and Al-Brahim, A. M.,"Discharge Equation for Proposed Self-Cleaning device" J. of King Saud Univ., Eng. Scie., Riyadh, Saudi Arabia, Vol. 9, No.1, pp. 13-24, 1997.

4. Ansar, M.,"Discussion of Simultaneous Flow Over and Under a Gate" J. of Irrig.\& Drain. Eng., pp. 325-328, 2001.

5. Bos, M. G., Clemmens, A. J. and Replogle, J. A.,"Design of long-throated structures for flow measurement", Irrig. and Drain. Syst.1, pp. 75-92, 1986.

6. Ferro, V.,"Simultaneous Flow over and Under a Gate", J. of Irrig.\& Drain. Eng., Vol. 126, No. 3, pp.190-193, 2000.

7. Göğüş, M., Defne, Z. and Özkandemir, V.,"Broad-crested weirs with rectangular compound cross sections”, J. of Irrig. \& Drain., Vol. 132(3), pp. 272-280, 2006.

8. Hager, W. H. and Schwalt, M., "Broad-crested weir", J. of Irrig. \& Drain. Eng., Vol. 120, No. 1, pp. 13-26, 1994.

9. Mohamed, H. I."Discharge measurement in trapezoidal lined canals utilizing horizontal and vertical transitions", $9^{\text {th }}$ Int. Water Tech. Conf. (IWTC9), Sharm El-Sheikh, Egypt, 2005.

10. Negm, A. M.,"Discharge Prediction Model for Simultaneous UnderflowOverflow" Proc. $6^{\text {th }}$ Int. Symp. On Flow Modeling and Turbulence Measurements, Florida, USA, 8-10, sep., Balkema Publishers, pp.665-670, 1996.

11. Negm, A. M.,"Characteristics of Simultaneous overflow-submerged underflow (unequal contractions)", Eng. Bulletin, Faculty of Eng., Ain Shams Univ., Cairo, Egypt, Vol. 35, No. 1, pp (137-154, 2000.

12. Negm, A. M.,"Experimental Investigation on Simultaneous Flow through Combined Box Culverts and Over Contracted Broad-Crested Weirs" Proc. $2^{\text {nd }}$ Int. Conf. for Advanced Trends in Eng., 7-9, April, Faculty of Eng., Al-Minia Univ., Egypt, 2002.

13. Negm, A. M., Abdel-Aal, G. M., Matin, A. M. and Alhamid, A. A.,"Discharge Equation for Free and Submerged Flow through Combined Weir" Proc. Of alAzhar Eng. $3^{\text {rd }}$ Int. Conf., Faculty of Eng., Al-Azhar Univ., Cairo, Egypt, pp. 456470, 1997.

14. Negm, A. M., Abdel-Aal, G. M., Matin, A. M. and Alhamid, A. A.,"Generalized Discharge Equation for Proposed Simultaneous Flow Structures" Proc. $6^{\text {th }}$ Of alAzhar Eng. Int. Conf.,1-4 Sept., Faculty of Eng., Al-Azhar Univ., Cairo, Egypt, pp. 247-257, 2000. 
15. Negm, A. M., Al-Brahim, A. M., Alhamid, A. A.,"Combined-free Flow over Weirs and below Gates", J. of Hyd. Res., Vol. 40, No. 3, pp.359-365, 2002.

16. Samani, J. M. V. and Mazaheri M.,"Combined Flow over Weir and under Gate" J. of Hyd. Eng., Vol. 35, No. 3, pp. 224-227, 2009.

17. Sargison, J. E. and Percy, A.,"Hydraulics of broad-crested weirs with varying side slopes”, J. of Irrig. \& Drain., Vol. 135, No. 1, pp. 115-118, 2009.

18. Wolters, W., ghobrial, N. S. and Eisa, M.,"Calibration of weirs in The Fayoum, Egypt", Irrig. \& Drain. Syst., 1, pp. 173-185, 1987.

\section{هيدروليكا الهدرات حرة السقوط ذات القتحات السفلية}

تستخدم الهدارات حرة سقوط المياه فى العديد من الأغراض الهيدروليكية مثل توزيع المياه وقياس معدلات التصرف بالقنوات المكثوفة وكذلك تخفيف فرق النوازن على القناطر • فى اقليم الفيوم تستخدم

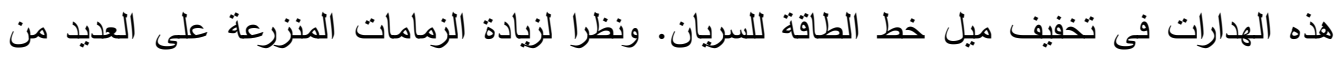

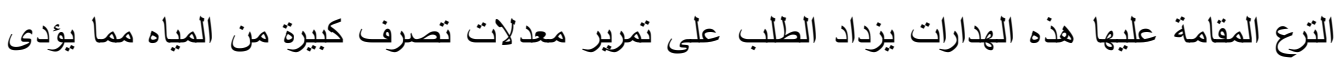
الى ارتفاع منسوبها أمام هذه الهدارات والذى بدوره يعمل على تهديد جسور القنوات الأمامية الدقامة

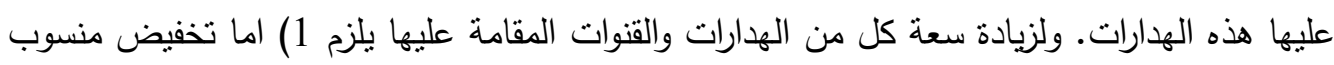
أعتاب الهدارات 2) زيادة عروضها أو 3) نتغيل وانشاء فتحات سفلية لتمرير المياه. المقترح الأول

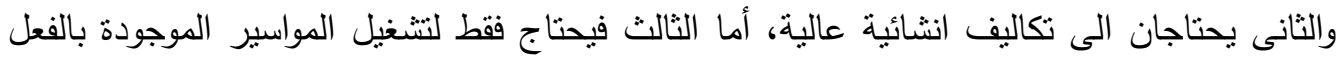
لغرض تجفيف الترع أثناء الصيانة. تشغيل هذه الفتحات يحتاج الى معرفة دقيقة وشاملة عن كميات المياه التى يمكن تمريرها من خلالها وكذلك يحتاج الى دراسة هيدروليكية عن الأثار الناتجة عن لتهن

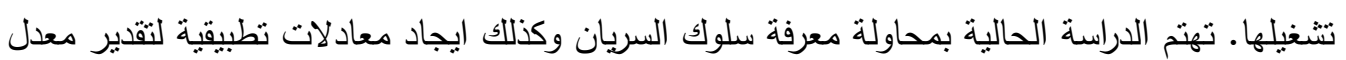
التصرف للسريان المجمع فوق الهدارات وخلال هذه الفتحات السفلية. أجريت الدراسة عمليا على نماذج للهدارات بارتفاعات مختلفة بها فتحات دائرية عند قيعانها وضعت التهات

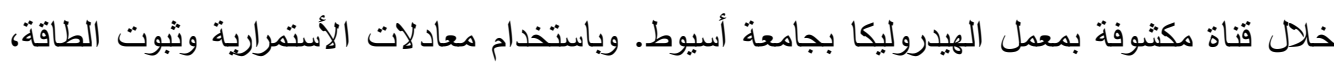
وكذلك نظرية الأبعاد، أمكن تحديد العوامل التى يعتمد عليها السريان. وباستخدام نظرية Regression Analysis معدل تصرف السريان المار خلال الفتحات وفوق الهدار كل على حدة وكذلك معدل السريان المجمع. 